\title{
The Role of School Counselor in Alleviation of Occupational Anxiety of Preschool Teachers
}

\author{
Fragoulis Iosif \\ As. Professor, School of Pedagogical and Technological Education \\ Tutor, Hellenic Open University \\ Sokratous 18, Kastelokampos, Rio, zc. 26504, Patra-Greece \\ Tel: 30-2610-910-066_E-mail: sfaka@otenet.gr \\ Papadopoulou Elisavet \\ Preschool teacher
}

Katerinis 2B, zc. 26223 Patra, Greece

Tel: 30-2610-434-877 E-mail: Elisave0@otenet.gr

\begin{abstract}
The complexity of teachers' work, the ever increasing demands of their role and the special conditions of their work environment are the cause of their work related anxiety.

The School Counselor (SC) can contribute to alleviate all occupational anxiety by means of support and leadership.

The aim of our project is to investigate the level of work related anxiety of preschool teachers, the factors contributing to this, as well as the contribution of the SC to its minimization. Finally, we portray the profile of the desirable leading figure of the-School Counselor, his/her role, and characteristics, as such are described by preschool teachers.
\end{abstract}

Keywords: Educational project, Role of a teacher, Occupational anxiety, School Counselor, Educational leadership

\section{INTRODUCTION}

It is common knowledge in our days that high quality learning and education contribute dramatically to economic, social and cultural development of countries (art. 38, L1340/2002, Eur. Parliament, 2008).

Therefore, it is imperative that effective and quality educational project be offered. In order to achieve this, all stakeholders involved in the educational process must cooperate - teachers, educational administrators, the state, parents (Balaskas, 1992:125).

The teacher constitutes one of the basic factors contributing to the success of the educational project (Douranou, 2007). However, the complexity of his/her new role, the changes in the educational environment and the special working conditions cause work related stress to the teacher, with adverse effects on him/her as well as the students and the whole educational system (Pappa, 2006).

Additionally, high quality and effective education demands administrative quality, meaning leadership, motivation, on-going training and, upon reaching the upper echelons of education, quality and effective management (Fassoulis, 2001).

\section{EDUCATIONAL PROJECT AND THE ROLE OF THE TEACHER IN MODERN EDUCATION}

\subsection{International perspectives and trends on the role of Education}

The European Parliament Report (2008) emphasizes the conviction that high quality learning, education, and teaching present multifaceted benefits, including the creation of work positions, the promotion of competitiveness, and the economic development of Europe in view of a globalised world. 
Also, it highlights the significant role of school with regard not only to the social and learning life of children, but their acquisition of the necessary knowledge and skills so that they will be able to participate in a democratic society (European Parliament, 2008).

A decade earlier (1998) OECD had already stressed the effort of states to modernize their educational systems so that education can contribute to their economic development, thus creating a new educational reality.

\subsection{Educational project}

As educational project we define "the sum total of activities incurred by the state, the local leaders and all those working in a school unit with a view to achieving the goals and objectives of education, so as to improve education." (Balaskas, 1992:125).

The European Commission for Education in a relative document notes that the ability of teachers to offer proper education to all their students, to create an atmosphere in which everybody can survive and to eliminate violent behavior is closely related to the conditions under which they work, the existing means of support, the number of students in a school, the cooperation with their families, and the received social support. -The extent to which teachers are engaged depends largely on the engagement of society to education, and the two factors interact for the benefit and improvement of education. (European Parliament, 2008)

\subsection{The teacher's role today}

Among the promoted changes concerning the changes in the methods of learning and teaching, the teacher's role, experience, knowledge, motivation and organization are necessary for the successful restructuring of educational systems. - The continuous renewal of knowledge and the acquisition of new skills are indispensable in keeping his/her professional status and the promotion of his/her flexibility (OECD, 1998).

After all, UNESCO's World Report on Education mentions that "in most countries what society expects from teachers is disproportionate, we would say, to the concessions the society is willing to make so as to reward them for their efforts in view of the means provided to them" (Iliou, 1996a:29).

All in all, the gravity of the teacher's role is great in the materialization of educational policy, as well as in the ensuing difficulties of daily school life, which under certain conditions may have significant negative implications on the teacher and the remaining educational and, therefore, the wider community.

\section{WORK RELATED ANXIETY}

\subsection{Definition - Description of Work Related Anxiety}

Kyriacou and Sutcliffe (1978) define the occupational anxiety of teachers as a negative emotional reaction affected by the way in which individuals perceive a situation as threatening or unpleasant, and by the mechanisms activated so as to deal with it.

After all, in a Convention of the International Labor Organization (I.L.O.) during the analysis of the work of modern teachers, it was emphasized that their work load is affected not only by the number of hours they work, but also the volume of specific tasks, as well as the tension accompanying them, which constitutes a source of mental fatigue ever dominating their well being as well as the quality of their teaching (Iliou, 2000:45).

Indeed, studies indicate that teaching comprises a stressful occupation and such stress has increased as the relation between society and education has become more complex (Kelly \& Berthelsen, 1995).

In its corroborated reports, I.L.O. has repeatedly emphasized that the stress experienced by teachers affects not only them personally, but the quality of their professional work and, consequently, the investment society has made on them. (Iliou, (b), 1996:28).

\subsection{Causes and Factors Contributing to Work Related Anxiety}

The following factors appear to affect the stress level experienced by a teacher:

- The conflict of roles and the haziness of the role, as well as the demands of the role and the complexity of the educational project.

- The structure of the occupational environment of teachers: uncertainty and insecurity caused by constant changes in educational policies (Younghsband, 2006), inability for intervention in decision making even when dealing with issues concerning them directly (Koustourakis, Ranagiotakopoulos \& Katsillis., 2000:124).

- The perception of a teacher as incapable of coping with occupational demands (Kelly \& Berthelsen, 1995). 
- The truncated ability to confront occupational demands, due to unsatisfactory work and environmental conditions, such as students' disobedience (Kelly \& Berthelsen, 1995), their lack of motivation, unwillingness for learning, poor work conditions (Kelly \& Berthelsen, 1995), insufficient material substructure (Pappa, 2006:136), time shortage for the completion of the educational project the and solution of problems (Avedisian, Koumpias \&Giavrimis. 2002:122).

- $\quad$ Extraneous and new occupational demands (Younghusband, 2006)

- Insufficient communication and interpersonal relations with students, their parents, and colleagues (Younghusband, 2006).

- Factors impertinent to the role of a teacher (Pappa, 2006:137).

Finally, in our days teachers are confronted with many more stressful situations, such as:

- The increase of the number of students with learning and behavioral difficulties. Teachers' insufficient education and training results in their experiencing a feeling of professional insecurity and ineffectiveness (Goodland \& Fields, 1993).

○ The large number of alien and returning emigrants enrolled in modern Greek schools (Pappa, 2006:140).

\subsection{Implications of Work Related Anxiety: the Concept of Occupational Fatigue}

An individual's inability to adjust to his/her occupational demands due to long lasting and painful work related stress exceeding his/her tolerance limits, leads to occupational fatigue (Avedisian et al., 2002:105).

According to Hendrickson, teachers' fatigue is corporal, emotional and psychological exhaustion starting when a teacher is overwhelmed by the feeling of disinterest in teaching (Pappa, 2006:138).

All in all, when a teacher experiences intense stress, various aspects if his/her performance are affected, such as creativity and implementation of teaching techniques, as well as the performance of his/her students. A recent study indicates that a teacher experiencing occupational fatigue feels lassitude, lack of enthusiasm, is overcome by the feeling of discontentment, has difficulty concentrating, and loses self confidence and personal sense of humor (Pappa, 2006:139).

Additionally, the negative consequences of work related anxiety on all offered education are marked out in OECD (2004) proposals, where the reduction of work related anxiety, the amelioration of work conditions and the professional development of educators are, among others, some of the measures to be taken for the improvement of effectiveness and quality of the educational project.

\subsection{Proposals for Dealing with Stressful Situations}

Therefore, teachers must be helped by being offered as many creative and essential outlets as possible.

The following are strategies to be implemented:

- The improvement of the occupational environment conditions, the management of classroom problems, the understanding and solving of students' needs.

- The training of educators in the confrontation of stressful situations.

- The support of educators in exercising their role by means of emotional counseling and guidance (Pappa, 2006:140).

On the level of Educational Administration, Executives (School Counselors, Principals and Supervisors) must operate supportively towards teachers, helping when need arises, exempting them from bureaucratic disfunctions and reinforcing every innovative efforts (Paraskeva, Papagiannis, 2008:208, Younghusband, 2006).

Ensuing the aforementioned confrontational interventions for stressful situations emerges the significant role of the School Counselor, whose guidance and support of teachers in their educational and teaching work is most important.

\section{LEADERSHIP AND MANAGEMENT IN EDUCATION - THE ROLE OF THE SC}

\subsection{The Institutional Role of the SC}

The SC constitutes one of the basic contributors to the educational project of a school unit and the work of its teachers. 
His/her duties include "the scientific-educational guidance and the participation in the assessment and training of teachers, as well as the encouragement of every scientific effort in the realm of education." (GG 1340/2002, v.B).

Following the description of the mission and the role of the $\mathrm{SC}$, we appreciate the necessity of the leadership goal of the SC, as it will be described in detail.

\subsection{The Necessity for Leadership and Management in Education - Educational Management}

According to Kotter, leadership and management are complementary and intersubjective systems-roles. Usually, despite its ambiguity, the perfect combination of these is a real challenge ensuring the highest possible yield and simultaneously man's highest satisfaction (Bourantas, 2002,313).

The role of the implementation of policies and the maintenance of a functional and effective organization on the level of its daily functions is attributed to management, whereas the role of policy making, dealing with changes and generally lofty objectives related to the improvement of staff, students and the educational project is attributed to leadership (Flouris, 2008). However, it is imperative that these constitute elements of the organizational culture of an organization so that management and leadership can develop (Papastamatis, 2008:254).

It is particularly important for education that executives function as leaders, being able to guide, coordinate, oversee and control the activities of their colleagues, inspire them, motivate them and contribute to the improvement of their cooperation. Also they must resume initiatives for their professional development and improvement as well as the development of a positive communication milieu (Katsaros, 2008:76-77).

However, the motivation of the human resources and the formulation of strategic incentives remains one of the most difficult activities in view of the vertical and inflexible bureaucratic hierarchy of the Greek educational system. (Katsaros, 2008:80, Andreou, Papakonstantinou, 1994:72).

\subsection{The SC as a modern leader and his/her contribution towards the elimination of teachers' work related anxiety}

The role of an executive in education consists of offering high level services towards the modernization and improvement of productivity of the organizations he/she manages (Anthis, Kaklamanis, 2005:117).

The SC can contribute, to the extent of his/her capability and role, as such is defined by the State as well as by modern leadership trends, towards the elimination of teachers' work related anxiety, intervening with regard to some important factors.

Teachers should be able to see the SC as a sympathizer who will consult them, will diagnose their weaknesses, will help them in their effort to cope with their difficulties, and will support them so as to boost their self consciousness and improve their living conditions inside and outside the school (Lazaridis, 2005:189).

Regarding the teaching tasks of teachers, the SC will be able to help in their organization, planning and realization, as well as in the management of problems related to classroom order (P.I., 2008:82-83).

Moreover, he/she can contribute to the professional and occupational development of teachers by means of programs for lifelong learning and ongoing training which will combine theory and action and will offer opportunities for the continuous improvement of their educational project (P.I., 2008:370-371), 379-381).

Finally, a great part causing stress to teachers, and to which the SC can contribute, is that of the communication between teachers and all stakeholders in the educational process, such as students, colleagues, parents, executives, whom he/she can meet with. Also, he/she can propose to teachers methods for more effective communication (P.I., 2008:83-83).

The SC comprises the link between science, the reality of the educational system and the objectives of his/her future development and of those teachers surrounding him/her. In managerial terms, he/she is the 'motivator in the middle.' (Lazaridis, 2005:10)

The description of a study investigating the SC's role towards the elimination of work related anxiety among kindergarten teachers follows.

\section{METHOD}

\subsection{Purpose of the Study and Research Questions}

The goal of this specific study is to investigate the amount of work related anxiety among kindergarten teachers and manifest the SC's role towards the elimination of such occupational stress.

Our research goals include: 
- The identification of the level and the factors contributing to occupational stress among kindergarten teachers.

- The way that the supportive and consultation role of the SC can eliminate the occupational anxiety among kindergarten teachers.

- The leadership profile of the SC conceived by kindergarten teachers.

Based on the research objectives mentioned above, we came up with the following research questions:

- Occupational anxiety among kindergarten teachers relates to demographic data.

- $\quad$ Factors contributing to occupational stress relate to demographic characteristics.

- The SC's role in eliminating the occupational anxiety of kindergarten teachers depends on their demographic characteristics.

- $\quad$ The profile of the desirable SC among kindergarten teachers depends on their demographic data.

\subsection{Sample}

The sample of our study consists of 149 subjects chosen among the 369 kindergarten teachers serving in Achaia in May 2009.

For the realization of the study we selected our subjects randomly using random numbers proportionately layered in Kindergarten Schools located

- $\quad$ In rural areas and big villages in the prefectures (39),

- In urban centers (72) and

- $\quad$ In suburban areas (38) (Cohen \& Manion, 1997:12)

\subsection{Methods for data collection}

In the specific study we picked triangulation as the main method. Specifically, we used questionnaires and interviewing techniques.

\subsubsection{Questionnaire}

A survey questionnaire was used as the technique of data collection, an instrument that is widely utilized in social sciences, since a large amount of data is collected in a short period of time. Regarding the methodology employed for the development of the questionnaire, it was based on formulated research questions on one hand, and on the bibliography and pre-scientific questions with individuals who belonged to the same target goal, and the SCs of the Prefecture of Achaia.

Concerning the validity assurance we applied

- A pilot study to ensure that adequate time was allowed for the questionnaire's completion and that all individuals were capable of comprehending its items. The questionnaire was first given to 20 preschool teachers working in public schools at the same time, in other areas.

- $\quad$ Internal check (Sudman \& Bradburn, 1983:167-168).

- Groups of questions about the same issue

\subsubsection{Interview}

To further ensure the validity of the answers to the questionnaires we employed the structured interview. Therefore, 5 preschool teachers from the Prefecture of Achaia, who had not been given the questionnaire, were submitted to a structured interview, each one lasting 20 minutes and each one, revolving around the same axes to those of the questionnaire, responded to 15 questions

\section{Table 1. Demographic data}

\section{DATA ANALYSIS AND RESULTS}

\subsection{Factors and Levels of Work Related anxiety}

Question: "To what degree do you consider the following factors to cause stress?"

According to the responses of the subjects a very high level of stress is caused by: 71 subjects $(47.7 \%)$ the very large number of students, 60 subjects $(40.3 \%)$ students with learning disabilities, 58 subjects $(38.9 \%$ students with behavioral problems. Analytically the responses are displayed in the following table. 
Based on the two-variable analysis, statistical significance $(a \leq .05)$ was observed among the variable age $(p=.005)$ : preschool teachers in the age group 34-43 years feel greater amount of stress with regard to parents and colleagues and also in assuming duties other than teaching.

Studies $(\mathrm{p}=.010)$ : the preschool teachers who hold a second or graduate degree or have participated in training programs show less occupational stress concerning several contingencies in their project and their daily work life.

Years of service $(\mathrm{p}=009)$ : the fewer the years of service of the subjects, the higher the degree of occupational stress, with regard to communication and parents and collueagues. Such find is corroborated by similar studies indicating that educators with fewer years of service showed more severe signs of occupational fatigue (Avedisian et at., 2002, Panagiotakopoulos, \& Katsilis, 1998).

Table 2. Factors contributing to Occupational Stress

\subsection{SC's Role in the Elimination of Work Related Anxiety among Preschool Teachers}

Question: "To what degree do you consider occupational stress to be relieved by the following?"

The subjects responded that stress would be very much alleviated by: the organization of preschool teachers' network for the support of educators regarding problems revolving around school daily life (38 subjects, 25.5\%), the cooperation with the SC for the planning and organization of the educational project (39 subjects, 26.2\%), the participation in training seminars (30 subjects, 20.1\%). Analytically the responses are displayed in the following table.

Based on the two-variable analysis, statistical significance $(a \leq .05)$ was observed among the variable age $(p=.007)$ and years of service $(\mathrm{p}=.000)$.

\section{Table 3. SC's Role in the Alleviation of Occupational Anxiety Experienced by Preschool Teachers}

Question: "Do you consider that close cooperation with the SC could alleviate your work related stress?"

142 subjects $(83.2 \%)$ responded positively and 25 subjects $(16.8 \%)$ negatively. When requested to delineate the way, $75 \%$ of the subjects answered they preferred the way of consultation and support, $32 \%$ preferred lifelong learning and training, $21.3 \%$ preferred support in communication and interpersonal relations, and $11.2 \%$ preferred the SC's support in matters pertinent to Administration and Law.

\subsection{Leadership Role and Characteristics of the SC}

Question: "Do you consider the SC should..."

All 149 subjects $(100 \%)$ answered that preschool teachers should participate in the decision making and the SC should seek their approval, 148 subjects (99.3\%) responded that the SC's communication with preschool teachers should be two-way and promote group work. Analytically the responses are displayed in the following table.

Based on the two-variable analysis, statistical significance $(a<.05)$ was observed among the variable Studies $(\mathrm{p}=.014)$ and years of service $(\mathrm{p}=.040)$.

\section{Table 4. Leadership Role and Characteristics of the SC}

\section{CONCLUSIONS - DISCUSSION}

Upon examination of the results of the study it is ascertained that:

$1^{\text {st }}$ and $2^{\text {nd }}$ Questions

- Students with learning difficulties and students with behavioral problems are considered to have a very high level of stressful effect. Following the teachers' views, it appears that their training with regard to the management of problematic behaviors presented at school is inefficient. Similar results were taken in relative studies (Kelly and Berthelsen, 1995, Younghusband, 2006).

- The large number of students in the classroom was found to be the most stress causing factor. Such finding is in agreement with relative studies (Tsiakkiros \& Pasiardis, 2002, Younghusband, 2006) and could be combined with the responsibility of teachers for the safety of children, the lack of assisting staff and the pressure of time, factors equally responsible for causing stress to preschool teachers.

- An additional group of factors adding to stress is that pertaining to poor building structure and the existing inefficiencies in material substructure and visual aids. Occupational stress caused by poor 
working conditions and lack of material substructure is supported by older studies (Kantas, 2001, Westwood, 1991, Avedisian et at., 2002).

- The pressure of time and extreme work loads were also suggested as particularly stressful factors. Should this be examined together with the multiple duties to which they are expected to respond together with their educational project, the continuous interruptions due to them, the lack of special staff and at the same time the demands of new curricula, it is easily appreciated that there is a disproportion between the demands made on preschool teachers and the existing time (Kantas, 2001, Kelly \& Berthelsen, 2006, Tsiakkiros \& Pasiardis, 2002).

- $\quad$ On the contrary, it was found that the subjects that participated in our study do not consider or consider less significant stressful factors the lack of communication with students, the lack of discipline, the adjustment of preschoolers to their new environment, the lack of interest of their students, the aliens and returning emigrants.

The finding support and underline previous results, as it is becoming ever more evident that preschool teachers feel anxiety, not due to the educational process, but due to all those events that occur or do not occur outside and around the educational process.

$3^{\text {rd }}$ Question

The SC's contribution to the alleviation of occupational stress experience by preschool teachers can be materialized by means of the following actions.

- The organization of a network of preschool teachers for the support of teachers and the discussion of pertinent matters concerning daily life at school. This finding appears to corroborate older studies holding that educators seek the support they need in order to face increasing occupational duties and relieve their occupational stress in relations with their colleagues (Kourtesi \& Kantas, 2000, Borg, 1990).

- The cooperation with the SC for the planning and organization of the school curriculum. SCs themselves consider particularly significant the reinforcement of the teacher's role as a planner and coordinator of the educational project, the utilization and development of the existing teaching experience of teachers and the organization and presentation of teaching lessons (P.I., 2008:82, 382).

- The attendance of training seminars. After all, international trends support the necessity for a transition from formal to fragmentary training involving lifelong learning with a view to creating a new professional perspective (P.I., 2009:5).

The response to our $3^{\text {rd }}$ question, following all the above, is that the School Counselor, by means of his/her supportive and advisory role can contribute to the alleviation of work related anxiety experienced by preschool teachers, and can do so in all the ways that the subjects suggested in the study.

$4^{\text {th }}$ Question

Through all the responses to the questions of the study, preschool teachers describe a participative leadership model of the SC. Specifically, they describe a leader who takes decisions and sets goals by means of consensus and democratic processes, in a climate of mutual trust and acceptance, who aims at two-way communication and group work, who clearly delineates roles and demands, and who trusts his/her own leadership ability.

The participation style of leadership, following Likert's typology, is based on the principle of a leader's full trust on the members of the organization. Decisions are taken in democratic processes in which all involved stakeholders participate. There is always an effort made for agreement and the principle of the majority prevails. The correct function of two-way communication is pursued and group work as well as group results and rewards are widely employed. What determine the level of communication in the organization and the decision taking system so that the group will be led to maximum productivity and high quality results is the leadership policies and practices, the abilities and the behavior of a leader. (Bourantas, 2002:331-332).

At this point it is necessary to be emphasized that the implementation of the principles of Management and the management of human resources on behalf of SC is not an easy process and the pertinent knowledge, skills and attitudes are not acquired by means of short term seminars. On the contrary, their development is long lasting and complex process which requires continuous and intensive efforts, education and training (Papastamatis, 2008:253).

In conclusion: 
- Preschool teachers experience occupational anxiety caused by several factors existing in their occupational environment.

- $\quad$ The SC can contribute to the alleviation of such anxiety by means of specific actions, activities, and initiatives

- The role of the SC as delineated by preschool teachers is advisory, supporting, mediating, reinforcing, and training.

- $\quad$ Preschool teachers describe the SC as an involving democratic leader.

\section{References}

Andreou, A., \& Papakonstantinou G. (1994). Authority and Organization-Administration of the Educational System. Athens: Nea Synora-Livani. (in Greek).

Anthis, X., \& Kaklamanis, Th. (2005). Administrative executives in education: from theory to practice in the $2^{\text {nd }}$ Panhellenic Congress on Primary and Secondary Education, volume 2, pp 108-119. Patras: Pantelis Georgogiannis. (in Greek).

Avedisian-Pagoropoulou, A., Koubias, \& E, Giavrimis, P. (2002). Occupational exhaustion syndrome: the long-term anxiety of teachers and its development to occupational exhaustion. [Online] Available: http://www.pi-schools.gr/publications/mentor/Mentoras5.zip (31/1/2009). (in Greek).

Balaskas, K. (1992). The demand for objective assessment of the educational project and its problems. In Two-day Convention of F.O.P.S.T. (Federation of Private School Teachers), Athens: Publishing Firm of Teachers- Writers. (in Greek).

Borg, M.G. (1990). Occupational stress in British educational settings: A review. Educational Psychology, Vol. 31, pp. 665-699.

Bourantas, D. (2002). Managements. Athens: Benou. (in Greek).

Cohen, L., \& Manion, L. (1997). Research Methods of Education. Athens: Ekfrasi. (in Greek).

Douranou, A. (2007). OECD's views on the new role of the Educator. [Online] Available: http://www.syllogosperiklis.gr/ep_bima/epistimoniko_bima_7/03_doyranoy.pdf (31/1/2009). (in Greek).

European Parliament. (2008). Review on the improvement of the quality of teachers' training. [Online] Available: http://europarl.europa.europa.eu/sides/getDoc.do?pubRef=-//EP??TEXT+REPORT=A6-2008-0304+0+DOC=X $\mathrm{ML}+\mathrm{VO} / / \mathrm{EL}(31 / 1 / 2009)$. (in Greek).

Fasoulis, K. (2001). Quality in the management of education human resources. A critical approach to the system "Holistic Quality Administration". [Online] Available: http://www.pi.schools.gr/publications/epitheorisi/teyxos4/ (31/1/2009). (in Greek).

Goodlad, J. \& Fields, S. (1993). Teachers for renewing schools. In G.G. Goodlad \& T.C. Lovitt (Edit.) Integrating general and special education, (pp. 229-252). New York: Merrill, McMillan Publishing Co.

Iliou, M. (1996a). Teacher's role today. Synhroni Ekpedefsi, Vol. 90-91, pp. 45-46. (in Greek).

Iliou, M. (1996b). Work conditions for teachers: stress and occupational fatigue. Synhroni Ekpedefsi, Vol. 89, pp. 27-28. (in Greek).

Iliou, M. (1998). The teachers' world: development and diversification of their roles. Synhroni Ekpedefsi, Vol. 113, pp. 45-46. (in Greek).

Kantas, A.. (2001). Stress factors and occupational fatigue among teachers, In E. Vasilaki, S. Triliva \& I. Bezevegis (Edit.) Stress, anxiety and their treatment, (pp. 217-230). Athens: Ellinika Grammata, Vol. 89, p. 27-28. (in Greek).

Katsaros, I. (2008). Organization and Administration in Education. Athens: YPEPTH. Pedagogical Institute. (in Greek).

Kelly, A., Berthelsen, D. (1995). Preschool Teachers' experiences of Stress. Teaching \& Teacher Education, Vol. 11, 4, pp. 345-357.

Kourtesi, P. \& Kantas, A. (2000). Strategies to face teachers' stress. Synhroni Ekpedefsi, Vol. 114-115, pp.56-66. (in Greek) 
Koustourakis, G., Panagiotakopoulos, H., \& Katsillis, G. (2000). Sociological approach of self assessed stress among teachers caused by the introduction of New Technologies in the educational prodcess: The case of the "stress over computers." Synhroni Ekpedefsi, Vol.110, pp.122-131. (in Greek).

Lazaridis, I. (2005). The role of the School Counselor. In $2^{\text {nd }}$ Panhellenic Congress on "Primary and Secondary Education, vol. 2. Patras: Pantelis Georgogiannis. (in Greek).

OECD, Education Policy Analysis. (1998). Paris. [Online] Available: http://eric.ed.gov/ERICWebPortal/custom/portlets/recordDetails/detailmini.jsp?_nfpb=true\&_\&ERICExtSearch_ SearchValue_0=ED422409\&ERICExtSearch_SearchType_0=no\&accno=ED422409 (31/1/2009) (in Greek).

Panagiotakopoulos, H., Koustourakis, G., \& Katsillis, G. (1998). Social implications of the advent of Computers in out lives: Detection of "stress over computers," Synhroni Ekpedefsi, Vol. 102, pp.112-120. (in Greek).

Papakonstantinou, P. (1993). Educational Project and assessment at school. Athens: Ekfrasi. (in Greek).

Papastamatis, A. (2008). The meaning of leadership and management in education. In On-going training of Education Executives: Action - Results - Prospects. Minutes from the Congress in Volos, pp. 247-257. Athens: YPEPTH, Pedagogical Institute. (in Greek).

Pappa, V. (2006). Stress among teachers and the factors contributing to occupation exhaustion. [Online] Available: http://www.pi.schools.gr/download/publications/epitheorisi/teyxos11/f14.pdf (31/1/2009). (in Greek).

Paraskeva, F., \& Papagiannis, A. (2008). Scientific and educational skills for education executives. Athens: YPEPTH, Pedagogical Institute. (in Greek).

Pedagogical Institute. (2008). Quality education: A study for the assessment of quality characteristics of the primary and secondary education system. [Online] Available: http://pi-schools.gr/programs/erevnes/index_axiol.php (10/8/2009). (in Greek).

Pedagogical Institute. (2009). Proposal for teachers' on-going training. [Online] Available: http://pi-schools.gr/paideia_dialogos/prot_epimorf.pdf (30/7/2009). (in Greek).

Sudman, S. \& Bradburn, N. (1983). Asking Questions. San Fransisco: Jossey-Bass.

Tsiakkiros, A., \& Pasiardis, P. (2002). Occupational Stress among teachers and school principals: A quality approach. Pedagigiki Epitheorisi 33, 195-213. [Online] Available: http://dspace.lib.uom.gr/bitstream/2159/4223/1/pasiardis_p.105-p.213_2002.pdf (21/1/2009). (in Greek).

Westwood, P. (1991). A shrinking service (editorial). Australian Journal of Remedial Education, 23, 1.

Younghusband, L. (2006). Teacher stress and working environments. Implications for Teaching and Learning. [Online] Available: http://www.mun.ca/harriscentre?Memorial_Presents/Teacher_Stess/NO_article.pdf $(6 / 7 / 2009)$. 
Table 1. Demographic data

\begin{tabular}{lrr}
\multicolumn{1}{c}{ Demographic data } & & $\underline{\boldsymbol{N}}$ \\
Age & & \\
$24-33$ & 31 & 20,8 \\
$34-43$ & 82 & 55 \\
$44-53$ & 34 & 22,8 \\
54 and over & 2 & 54
\end{tabular}

\section{Working area}

Urban

$72 \quad 48,3$

Suburban

$38 \quad 25,5$

Rural

$39 \quad 26,2$

Years of service

1-9

$72 \quad 48,3$

10-19

$50 \quad 34,2$

20-29

$20 \quad 13,4$

30 and over

6

4

\section{Studies}

2o degree

$11 \quad 7,4$

Master's degree

$17 \quad 11,4$

No participation in training programs

$109 \quad 73,2$


Table 2. Factors contributing to Occupational Anxiety

\begin{tabular}{|c|c|c|c|c|c|c|c|c|c|c|c|}
\hline \multirow{2}{*}{ Factors leading to occupational anxiety } & \multicolumn{2}{|c|}{ Very high } & \multicolumn{2}{|c|}{ High } & \multicolumn{2}{|c|}{ Enough } & \multicolumn{2}{|c|}{ Very little } & \multicolumn{2}{|c|}{ None } & \multirow[t]{2}{*}{ mean } \\
\hline & & $\%$ & & $\%$ & & $\%$ & & $\%$ & & $\%$ & \\
\hline The large number of students in a class & 71 & 48 & 36 & 24 & 27 & 18 & 11 & 7,4 & 4 & 2,7 & 4,07 \\
\hline Students' behavioral problems & 58 & 39 & 49 & 33 & 32 & 22 & 6 & 4 & 4 & 2,7 & 4,01 \\
\hline Students with learning difficulties & 60 & 40 & 47 & 32 & 28 & 19 & 10 & 6,7 & 4 & 2,7 & 4 \\
\hline Insufficient material substructure & 52 & 35 & 46 & 31 & 33 & 22 & 15 & 10 & 3 & 2 & 3,87 \\
\hline Insufficient pedagogical and visual aids & 51 & 34 & 45 & 30 & 37 & 25 & 13 & 8,7 & 3 & 2 & 3,86 \\
\hline Poor building substructure & 51 & 34 & 44 & 30 & 32 & 22 & 17 & 11 & 5 & 3,4 & 3,8 \\
\hline Pressure of time & 43 & 29 & 39 & 26 & 44 & 30 & 17 & 11 & 6 & 4 & 3,64 \\
\hline Excessive load of work & 33 & 22 & 44 & 30 & 47 & 32 & 18 & 12 & 7 & 4,7 & 3,52 \\
\hline Changes to educational policies & 24 & 16 & 48 & 32 & 55 & 37 & 17 & 11 & 5 & 3,4 & 3,46 \\
\hline New/unknown occupational demands & 29 & 20 & 39 & 26 & 50 & 34 & 25 & 17 & 6 & 4 & 3,4 \\
\hline Changes to the curricula & 32 & 22 & 36 & 24 & 47 & 32 & 26 & 17 & 8 & 5,4 & 3,39 \\
\hline Unclear duties & 16 & 11 & 51 & 34 & 58 & 39 & 21 & 14 & 3 & 2 & 3,38 \\
\hline Work demands & 22 & 15 & 45 & 30 & 56 & 38 & 20 & 13 & 6 & 4 & 3,38 \\
\hline $\begin{array}{l}\text { Duties beyond the kindergarten teacher's } \\
\text { role }\end{array}$ & 29 & 20 & 32 & 22 & 62 & 42 & 16 & 11 & 10 & 6,7 & 3,36 \\
\hline $\begin{array}{l}\text { Decision taking on } \\
\text { administrative/educational issues }\end{array}$ & 15 & 10 & 43 & 29 & 66 & 44 & 21 & 14 & 4 & 2,7 & 3,3 \\
\hline $\begin{array}{l}\text { Parents' adjustment to school reality and } \\
\text { the ensuing demands (i.e. following } \\
\text { schedule, preparation of preschoolers, } \\
\text { cooperation with school etc) }\end{array}$ & 13 & 8,7 & 39 & 26 & 67 & 45 & 21 & 14 & 9 & 6 & 3,17 \\
\hline $\begin{array}{l}\text { Lack of effective communication and } \\
\text { development of interpersonal relations } \\
\text { with students' parents }\end{array}$ & 19 & 13 & 42 & 28 & 44 & 30 & 32 & 22 & 12 & 8,1 & 3,16 \\
\hline $\begin{array}{l}\text { Lack of effective communication and } \\
\text { development of interpersonal relations } \\
\text { with colleagues }\end{array}$ & 27 & 18 & 31 & 21 & 47 & 32 & 26 & 17 & 18 & 12 & 3,15 \\
\hline $\begin{array}{l}\text { Lack of effective communication and } \\
\text { development of interpersonal relations } \\
\text { with students }\end{array}$ & 28 & 19 & 28 & 19 & 36 & 24 & 36 & 24 & 21 & 14 & 3,04 \\
\hline Students' disobedience & 17 & 11 & 26 & 17 & 68 & 46 & 26 & 17 & 12 & 8,1 & 3,02 \\
\hline $\begin{array}{l}\text { Preschoolers' adjustment to the new } \\
\text { environment }\end{array}$ & 13 & 8,7 & 39 & 20 & 67 & 39 & 21 & 26 & 9 & 6,7 & 2,97 \\
\hline $\begin{array}{l}\text { Students' disinterest in participating in } \\
\text { daily activities }\end{array}$ & 9 & 6 & 25 & 17 & 65 & 44 & 40 & 27 & 10 & 6,7 & 2,89 \\
\hline Alien and emigrant students & 9 & 6 & 30 & 20 & 43 & 29 & 44 & 30 & 23 & 15 & 2,72 \\
\hline
\end{tabular}


Table 3. SC's Role in the Alleviation of Occupational Anxiety Experienced by Preschool Teachers

\begin{tabular}{|c|c|c|c|c|c|c|c|c|c|c|c|}
\hline \multirow{2}{*}{$\begin{array}{c}\text { SC's Role in Alleviating Occupational } \\
\text { Stress }\end{array}$} & \multicolumn{2}{|c|}{$\begin{array}{l}\text { Very } \\
\text { high }\end{array}$} & \multicolumn{2}{|c|}{ Hig } & \multicolumn{2}{|c|}{ Enough } & \multicolumn{2}{|c|}{$\begin{array}{l}\text { Very } \\
\text { litle }\end{array}$} & \multicolumn{2}{|c|}{ None } & \multirow[t]{2}{*}{ mean } \\
\hline & & $\%$ & & $\%$ & & $\%$ & & $\%$ & & $\%$ & \\
\hline Networks & 38 & 26 & 60 & 40 & 36 & 24 & 11 & 7,4 & 4 & 2,7 & 3,79 \\
\hline $\begin{array}{l}\text { Cooperation in planning educational } \\
\text { project }\end{array}$ & 39 & 26 & 53 & 36 & 37 & 25 & 17 & 11,4 & 3 & 2 & 3,72 \\
\hline Training Seminars & 30 & 20 & 56 & 38 & 45 & 30 & 14 & 9,4 & 4 & 2,7 & 3,63 \\
\hline Meetings with parents & 32 & 22 & 48 & 32 & 49 & 33 & 16 & 10,7 & 4 & 2,7 & 3,59 \\
\hline Meetings with Administrators & 36 & 24 & 44 & 30 & 47 & 32 & 16 & 10,7 & 6 & 4 & 3,59 \\
\hline Common projects with other teachers & 26 & 17 & 54 & 36 & 52 & 35 & 14 & 9,4 & 3 & 2 & 3,58 \\
\hline $\begin{array}{l}\text { Meetings with the Teachers' } \\
\text { Association }\end{array}$ & 25 & 17 & 45 & 30 & 54 & 36 & 21 & 14,1 & 4 & 2,7 & 3,44 \\
\hline
\end{tabular}

Table 4. Leadership Role and Characteristics of the SC

\begin{tabular}{|c|c|c|c|c|}
\hline \multirow{2}{*}{ Leadership Profile of the School Counselor } & \multicolumn{2}{|c|}{ Yes } & \multicolumn{2}{|c|}{ No } \\
\hline & & $\%$ & & $\%$ \\
\hline Takes decisions with the teachers' participation & 149 & 100 & 0 & 0 \\
\hline Pursues concession & 149 & 100 & 0 & 0 \\
\hline Pursues two-way communication with teachers & 148 & 99 & 1 & 0,7 \\
\hline Encourages and pursues group work & 148 & 99 & 1 & 0,7 \\
\hline Enjoys the teachers' trust & 145 & 97 & 4 & 2,7 \\
\hline Accepts teachers' particularities and needs & 143 & 96 & 6 & 4 \\
\hline Defines teachers occupational role thoroughly & 137 & 92 & 12 & 8,1 \\
\hline Defines his/her demands on teachers clearly & 137 & 92 & 12 & 8,1 \\
\hline Criticizes and rewards objectively & 132 & 89 & 17 & 11 \\
\hline Develops friendly and mutually trusting relations with teachers & 131 & 88 & 18 & 12 \\
\hline Sets goals and expects teachers to realize them & 122 & 82 & 27 & 18 \\
\hline Trusts his/her leadership ability & 112 & 75 & 37 & 25 \\
\hline $\begin{array}{l}\text { Takes decisions on serious issues alone and on those of less } \\
\text { importance with the teachers' participation }\end{array}$ & 39 & 26 & 110 & 74 \\
\hline Supports his/her authority on the post & 31 & 21 & 118 & 79 \\
\hline Maintains formal relations with teachers & 18 & 12 & 131 & 88 \\
\hline Instructs giving minimal elaborations and explanations & 11 & 7,4 & 138 & 93 \\
\hline Pursues one-way communication with teachers & 1 & 0,7 & 148 & 99 \\
\hline Takes decisions alone and relays information to teachers & 0 & 0 & 149 & 100 \\
\hline
\end{tabular}

